DOI https://doi.org/10.30525/978-9934-26-182-4-10

\title{
ДОЦІЛЬНІСТЬ ЗАСТОСУВАННЯ ОМЕГА-З-ПНЖК У ХВОРИХ ІЗ КОМОРБІДНОЮ ПАТОЛОГІЕЮ (ІХС + ЦД 2-ГО ТИПУ)
}

\author{
Ілащук T. O. \\ доктор медичних наук, професор, \\ завідувач кафедри пропедевтики внутрішніх хвороб \\ Буковинський державний медичний університет \\ м. Чернівиі, Україна \\ Горевич С. C. \\ аспірант кафедри пропедевтики внутрішніх хвороб \\ Буковинський державний медичний університет \\ м. Чернівиі, Україна \\ Скорейко Н. Т. \\ лікар-кардіолог вищої категорії \\ КП «Рівненська обласна клінічна лікарня імені Юрія Семенюка» \\ Рівненської обласної ради \\ м. Рівне, Украӥна
}

Цукровий діабет (ЦД) є важливою медико-соціальною проблемою насамперед унаслідок його поширеності, ранньої інвалідизації та передчасної смертності в результаті розвитку судинних ускладнень. Експерти Всесвітньої організації охорони здоров'я (ВОО3) називають ЦД однією 3 найнебезпечніших неінфекційних епідемій XXI століття, а експерти Міжнародної діабетичної федерації (МДФ) - загальносвітовою соціальною катастрофою [1, с. 24-25].

Мета: проаналізувати дані літератури та результати власних досліджень щодо доцільності та ефективності використання омега-3 поліненасичених жирних кислот (омега-3 ПНЖК) у пацієнтів із хронічною ішемічною хворобою серця (IXC) та ЦД 2-го типу.

ЦД 2-го типу є серйозним фактором ризику серцево-судинних захворювань (СС3), який на сьогоднішній день вважається еквівалентом серцево-судинного ризику. ССЗ є провідною причиною смерті людей у всіх країнах світу, незважаючи на той факт, що багато факторів серцевосудинного ризику є такими, які піддаються модифікації і при правильному підході піддаються корекції. Наприклад, добре відомо, що їжа, багата насиченими жирами, підвищує ризик СС3, тоді як вживання їжі, збагаченої омега-3-ПНЖК знижує цей ризик [2, с. 95-104].

Атерогенні дисліпідемії зустрічаються у 40-60\% хворих на ЦД 2-го типу і $\epsilon$ фактором ризику розвитку судинних ускладнень - діабетичної ангіопатії, IXC, порушень периферичного та церебрального кровообігу. 
Відома пряма кореляційна залежність між рівнем гіперінсулінемії та порушеннями ліпідного обміну, що дозволяє розглядати гіперінсулінемію як один із факторів розвитку та прогресування атеросклерозу. Порушення обміну речовин призводить до прискореного розвитку атеросклерозу судин серця, головного мозку та нижніх кінцівок.

Традиційна фармакологічна корекція зазначених патологічних станів проводиться за допомогою антиагрегантів, гіполіпідемічних та судинних засобів. Але деякі препарати мають цілий ряд неприємних побічних ефектів. До них відносяться порушення функції печінки, шлунковокишкового тракту, погіршення показників крові та алергічні реакції. В останні роки широкого розповсюдження набули лікарські препарати, що містять натуральні поліненасичені жирні кислоти омега-3, які можуть використовуватися як засоби профілактики та корекції атеросклерозу при діабеті 2-го типу [3, с. 633-651].

У 1971 р. в журналі Lancet була опублікована стаття [4, с. 1143-1145], в якій зазначалася інформація щодо нижчого порівняно 3 континентальними датчанами (відмінність статистично достовірна) вмісту у плазмі крові ескімосів атерогенних фракцій ліпопротеїнів, що пояснювалося особливостями харчового раціону ескімосів. Однак це повідомлення залишилося практично поза увагою. Ці спостереження надалі були підтверджені низкою великих епідеміологічних досліджень, у яких простежено та визначено зворотну статистично значущу кореляцію між рівнем омега-3 ПНЖК у плазмі крові та ризиком розвитку фатальних та нефатальних інфарктів міокарда.

Інтерес до омега-3 ПНЖК виник після публікації результатів датського епідеміологічного дослідження, в якому впродовж 24 років (1950-1974, кількість учасників - 1800) вивчалися особливості ССЗ гренландських ескімосів та континентальних датчан [5, с. 401-406]. Було встановлено, що ескімоси практично не хворіють на інфаркт міокарда, мультифокальний атеросклероз, цукровий діабет, тиреотоксикоз і псоріаз. Ці відмінності пов' язували з особливостями харчування ескімосів, а саме споживанням 3 їжею великої кількості омега-3 ПНЖК.

Наприклад, в епідеміологічному дослідженні Honolula Health Program (період спостереження за 8006 японцями - 1963-1988рр.) досліджували вплив дієти, багатої на морепродукти на ризик розвитку летальності від IXC [6, c. 952-956]. Результати цього дослідження свідчили, що в осіб, які систематично вживають в їжу морепродукти, багаті на омега-3 ПНЖК, ризик летальності від IXC значно нижчий $(\mathrm{p}<0,01)$.

Епідеміологічні дослідження гренландських вчених довели зворотній зв'язок між щоденним вживанням омега-3-ПНЖК та розвитком СС3, зокрема IXC. Омега-3-ПНЖК здатні контролювати рівень ліпідів у крові та запальні зміни в кардіоміоцитах та ендотеліальних клітинах судин [7, c. 2525-2545]. 
При цьому позитивна роль омега-3-ПНЖК (ейкозапентаєнової (ЕПК) і докозагексаєнової кислот (ДГК)) в первинній і вторинній профілактиці різних СС3 пов'язана не тільки з енергетичною і структурною функцією ЕПК і ДГК, а й з різноманітним захисним впливом цих кислот на різні компоненти серцево-судинної системи і фактори серцево-судинного ризику (табл. 1) [8, с. 47-51].

\section{Таблиця 1}

Кардіоваскулярні ефекти омега-3-ПНЖК

\begin{tabular}{|c|c|}
\hline Протизапальний & $\begin{array}{l}\text { 1) } \downarrow \text { активності NF-B } \\
\text { 2) Конкуренція ЕПК і ДГК з арахідоновою кислотою за } \\
\text { зв'язок з ЦОГ і 5-ліпооксигеназою, що призводить до } \\
\text { зниження активності утворення ІЛ-1, ІЛ-6 і ФНП- } \\
\text { альфа } \\
\text { 3) } \uparrow \text { утворення ейкозаноїдів - речовин } \\
\text { з протизапальною активністю }\end{array}$ \\
\hline $\begin{array}{l}\text { Вплив на } \\
\text { енергетичний обмін } \\
\text { у міокарді }\end{array}$ & $\begin{array}{l}\text { 1) } \quad \uparrow \text { активності утворення АТФ } \\
\text { 2) } \quad \downarrow \text { споживання О } 2 \\
3) \quad \quad \downarrow \text { концентрації кальцію у } \\
\text { саркоплазматичному ретикулумі, що сприяє підтримці } \\
\text { нормальної функції мітохондрій }\end{array}$ \\
\hline Антиаритмічний & $\begin{array}{l}\text { 1) } \uparrow \text { активності } \mathrm{Ca}^{2+/} \mathrm{Mg}^{2+}-\mathrm{ATФази} \\
\text { 2) пригнічення швидких потенціалозалежних } \\
\mathrm{Na}^{+} \text {-каналів } \\
\text { 3) пригнічення } \mathrm{Ca}^{+}-\text {-каналів L-типу, що призводить до } \\
\text { стабілізації мембрани } \\
\text { 4) зниження автоматизму } \\
\text { 5) подовження відносного рефрактерного періоду }\end{array}$ \\
\hline Гемодинамічний & $\begin{array}{l}\text { 1) покращення ендотелій-залежної } \\
\text { і ендотелій-незалежної вазодилатації } \\
\text { 2) } \downarrow \text { утворення ендотеліну-1 } \\
\text { 3) } \uparrow \text { утворення оксиду азоту, що призводить до } \\
\text { зниження ендотеліальної дисфункції }\end{array}$ \\
\hline $\begin{array}{l}\text { Ремоделювання і } \\
\text { фіброз міокарда } \\
\text { шлуночків серця } \\
\end{array}$ & $\begin{array}{l}\text { 1) } \uparrow \text { PPAR, що призводить до } \uparrow \text { синтезу адипонектину } \\
\text { i в результаті - до пригнічення ремоделювання } \\
\text { міокарда шлуночків }\end{array}$ \\
\hline Судинний & $\begin{array}{l}\text { 1) } \downarrow \text { агрегації тромбоцитів через } \downarrow \text { тромбоксану A2 } \\
\text { 2) } \downarrow \text { VCAM-1, ELAM-1, ICAM-1 } \\
\text { 3) } \downarrow \text { прилипання моноцитів до ендотелію через } \\
\text { фактору активації тромбоцитів }\end{array}$ \\
\hline
\end{tabular}

NF-B - ядерний фактор «каппа-бі»; VCAM-1 - молекула адгезії судинного ендотелію 1 типу; ELAM-1 - Е-селектин; ICAM-1 - молекула міжклітинної адгезії 1 типу; ІЛ - інтерлейкін; ФНП-альфа - фактор некрозу пухлин-альфа; ЦОГ - циклооксигеназа. 
Матеріали та методи. Нас також зацікавили можливості включення омега-3 ПНЖК у склад гіполіпідемічної терапії (омега-3 + статини) та можливі ефекти від використання даної комбінації, тому нами було обстежено 40 пацієнтів (26 чоловіків та 14 жінок) із хронічною IXC та ЦД 2-го типу. Хворих було поділено на 2 групи. Перша група отримувала монотерапію - розувастатин у дозі 20 мг на добу, друга група комбіновану терапію (розувастатин у дозі 10 мг на добу + омега-3-ПНЖК у дозі 2000 мг на добу). До та через 3 місяці після лікування у пацієнті визначали показники ліпідного обміну (загальний холестерин (3X), рівень ліпопротеїнів низької щільності (ЛПНЩ), ліпопротеїнів високої щільності (ЛПВЩ), тригліцеридів (ТГ).

Результати. Було встановлено, що застосування комбінованої терапії (розувастатин + омега-3-ПНЖК) у хворих на IXC та ЦД 2-го типу сприяє покращенню ліпідного профілю (зниженню рівня ЗХ, ТГ, ЛПНЩ, підвищення рівня ЛПВЩ). Також дана комбінація дозволила знизити дозу статину з метою попередження побічних дій препарату, але не знизила ефективність лікування за рахунок корекції схеми препаратами омега-3ПНЖК.

Висновки. Омега 3-ПНЖК мають широкий спектр біологічної активності та виражену терапевтичну ефективність, що дозволяє включати дані препарати у комплексне лікування пацієнтів з метою корекції порушень ліпідного обміну та, як наслідок - зниження ризику несприятливих серцево-судинних подій у майбутньому.

Використання у лікуванні хворих на IXC з ЦД 2-го типу препаратів омега-3 ПНЖК забезпечує зниження рівня 3Х, ТГ, ЛПНЩ та підвищення рівня ЛПВЩ та дозволяє знизити дозу статину, що дає можливість не знижуючи ефективність лікування, попередити побічні ефекти статинів у даних пацієнтів.

\section{Література:}

1. Біловол О.М., Князькова I.I. Дисліпідемії при цукровому діабеті. Здоров'я України 21 сторіччя. 2021. № 20 (513). С. 24-25.

2. Mori T., Woodman R. The independent effects of eicosapentaenoic acid and docosahexaenoic acid on cardiovascular risk factors in humans. Curr Opin Clin Nutr Metab Care. 2006. 9. P. 95-104.

3. Lorente-Cebrian S., Costa A., Navas-Carretero S. et al. Role of omega3 fatty acids in obesity, metabolic syndrome, and cardiovascular diseases: a review of the evidence. J Physiol Biochem. 2013. №69. P. 633-651.

4. Bang HO, Dyeberg J, Nielsen AH. Plasma lipid and lipoprotein pattern in Greenlandic West Coast Eskimos. Lancet. 1971. №1. P. 1143-45. 
5. Kromann N, Green A. Epidemiological studies in the Upernavir district, Greenland. Incidence ofsomet chronic disease 1950-1974. Acta Med Scand. 1980. №208(5). P. 401-6.

6. Rodriguez BL, Sharp DS, Abbott RD, et al. Fish intake may limit the increase in risk of coronary heart disease morbidity and mortality among heavy smokers. The Honolulu Heart Program. Circulation. 1996. №94(5). P. 952-56.

7. Donald B. Jump, Christopher M. Depner and Sasmita Tripathy. Omega-3 fatty acid supplementation and cardiovascular disease. J Lipid Res. 2012 December; 53:(12). P. 2525-2545.

8. Мицьо В. Кардиоваскулярные эффекты $\omega-3$ полиненасыщенных жирных кислот: влияние на прогноз после перенесенного инфаркта миокарда. Medical review. 2014. №2(30). P. 47-51.

DOI https://doi.org/10.30525/978-9934-26-182-4-11

\title{
ЗНАЧЕННЯ РЕЦЕПТОРІВ АНДРОГЕНІВ В ПЕРЕБІГУ ЗАХВОРЮВАННЯ У ПАЦІСНТОК 3 ТРИЧІ НЕГАТИВНИМ РАКОМ ГРУДНОЇ ЗАЛОЗИ
}

\author{
Лялькін С. А. \\ доктор медичних наук, старший дослідник, \\ старший науковий співробітник \\ Національний інститут раку \\ м. Київ, Украӥна
}

Андрогенові рецептори (АР) - стероїдні гормональні рецептори, які функціонують як класичний ліганд-активований інтрацелюлярний фактор транскрипції $[1,2]$. Експресія АР виражена в нормальній тканині грудної залози та більшості молекулярних підтипів раку грудної залози (РГЗ) $[2,3]$. Остаточну роль андрогенів у розвитку та прогресуванні РГЗ не встановлено. Наявність АР у пухлині залежить від молекулярного підтипу РГЗ і спостерігається у майже 90\% хворих на люмінальний А РГЗ, у 70-90\% - на люмінальний В РГЗ, у 60\% при HER2 позитивному типу та 10- 50 \% при тричі негативному РГЗ (ТНРГЗ) [4]. Слід зазначити, що прогностична та предиктивна роль АР для ТНРГЗ $є$ суперечливою. Дослідження Y. Kim et al. [5], продемонструвало, що для пацієнток 3 ТНРГЗ наявність експресії АР асоційована 3 кращим показником виживання без прогресування (ВР 0,42, 95\% ДІ 0,27-0,64). В мета-аналізі 